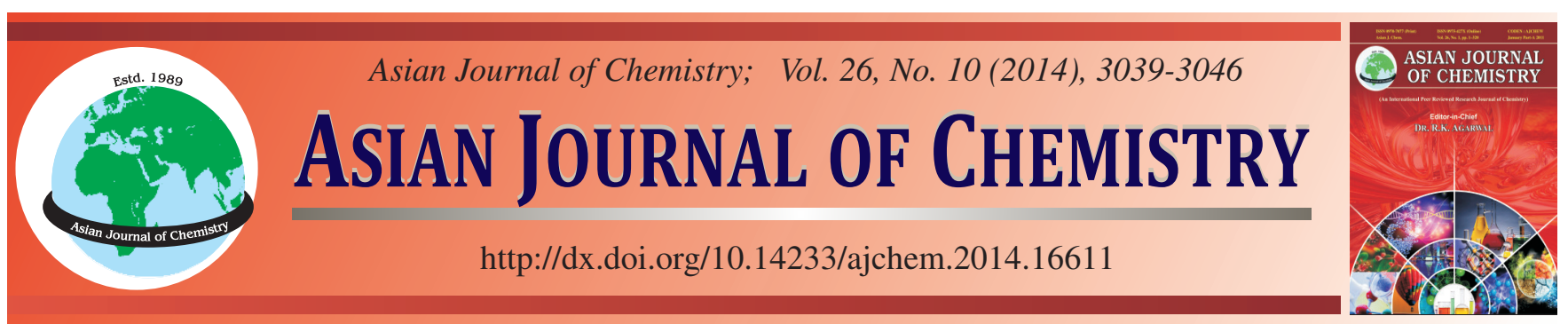

\title{
New Validated Carbon Paste and Modified Carbon Nanotubes Sensors for Selective Determination of Pantoprazole Sodium
}

\author{
Nawal Ahmad Alarfaj* and Maha Faroug El-Tohamy
}

Department of Chemistry, College of Science, King Saud University, P.O. Box 22452, Riyadh 11495, Saudi Arabia

*Corresponding author: E-mail: nalarfaj@ hotmail.com

\begin{abstract}
New validated carbon paste and chemically modified carbon nanotubes (MCNTs) sensors for determination of pantoprazole sodium (PA) were developed. The developed method was based on the fabrication of two types of sensors carbon paste (I), and modified carbon nanotubes (II). The employed sensors were fabricated using electroactive materials pantoprazole-phosphomolybdate (PA-PM). The performance characteristics of the proposed sensors were carefully studied. The sensors exhibited nearly Nernstain responses $(55 \pm 0.3$ and $57.3 \pm 0.8 \mathrm{mV}$ decade $\left.^{-1}\right)$ for pantoprazole-phosphomolybdate carbon paste and modified carbon nanotubes sensors at $25^{\circ} \mathrm{C}$ over drug concentration ranges $\left(1 \times 10^{-6}-1 \times 10^{-3}\right.$ and $\left.1 \times 10^{-7}-1 \times 10^{-2} \mathrm{~mol} \mathrm{~L}^{-1}\right)$ with lower detection limits of $\left(9.1 \times 10^{-8}\right.$ and $\left.9.8 \times 10^{-9} \mathrm{~mol} \mathrm{~L}^{-1}\right)$ for the previously mentioned sensors, respectively. The fabricated sensors were safely used at $\mathrm{pH} 4-8$ and displayed good isothermal coefficients 0.00105 and $0.00042 \mathrm{~V}^{\circ} \mathrm{C}^{-1}$ for pantoprazole-phosphomolybdate carbon paste and modified carbon nanotubes sensors, respectively. The influence of common and possible interfering species, pharmaceutical additives and some related pharmacological action drugs was investigated using both separate solution and mixed solution methods. No interference was found. The stability indicating using forced degradation of pantoprazole sodium was also studied. The results of the proposed method were validated and statistically analyzed by recoveries studies and compared with those obtained from previously reported methods. The proposed method was successfully applied for quantification of the investigated drug in pure form, its dosage forms and biological fluids.
\end{abstract}

Keywords: Pantoprazole sodium, Carbon paste sensor, Modified carbon nanotubes sensor, Biological fluids, Dosage forms.

\section{INTRODUCTION}

Pantoprazole sodium (PA) is a prescription drug that is most commonly used to remedy situations where there is an excess of stomach acid. It is therefore classified as a protonpump inhibitor; highly potent drugs that have the primary function of reducing gastric acid production for long durations ${ }^{1}$. It is chemically known as sodium 5-(difluoromethoxy)-2[[(3,4-dimethoxy-2-pyridinyl) methyl] sulfinyl]-1H-benzimidazole (Fig. 1).<smiles>CCCCOc1ccc2oc(C(=O)Cc3nccc(OC)c3OC)nc2c1</smiles>

Fig. 1. Chemical structure of pantoprazole sodium

The literature survey revealed that several methods have been reported for determination of pantoprazole sodium. These methods include high performance liquid chromatography $\mathrm{y}^{2-4}$, high performance liquid chromatography coupled with mass spectrometry $^{5-7}$, thin layer chromatography ${ }^{8}$, spectrophotometry ${ }^{9-11}$ and voltammetry ${ }^{12,13}$.

Carbon nanotubes (CNTs) are important new class of technological materials that have numerous novel and useful properties. They have received very much attention as new classes of nanomaterials. These are the long hollow seamless cylinders single walled as well as multi-walled carbon nanotubes of graphene ${ }^{14}$.

The aim of the present study is the development of two types of sensors carbon paste and modified carbon nanotubes for quantification of pantoprazole sodium in pure form, its pharmaceutical formulations and biological fluids.

\section{EXPERIMENTAL}

All chemicals used throughout the experimental analysis were of analytical grade. Distilled water was used throughout all measurements. Poly(vinyl chloride) (PVC) high molecular weight, phosphomolybdic acid (PMA) $99 \%$, high purity graphite powder $(1-2 \mu \mathrm{m})$ and multi-wall carbon nanotubes powder (carbon $>95 \%$, O.D. $\times$ L 6-9 $\mathrm{nm} \times 5 \mu \mathrm{m}$ ) were purchased 
from Sigma-Aldrich, Germany. Di-octylphthalate (DOP) 99.5 $\%$, di-butyl phthalate (DBP) $\geq 99 \%$, di-butylsebacate (DBS) $\geq 97 \%$, di-octylsebacate (DOS) $\geq 97 \%$ o-nitrophenyloctylether (o-NPOE) and tetrahydrofuran (THF) $97 \%$ were provided by Fluka, Switzerland. Sodium hydroxide $98 \%$, zinc sulphate $\geq$ $99 \%$, ethyl acetate, methanol, glacial acetic acid $\geq 99.7 \%$ and hydrochloric acid $36.5 \%$ were purchased from BDH laboratory supplies (England). Pure grade pantoprazole sodium was kindly supplied from Pfizer Co. (Egypt). The pharmaceutical preparation (Protonix ${ }^{\circledR} 40 \mathrm{mg} /$ tablet, Pfizer) was purchased from local drug stores. Phosphate buffer of $\mathrm{pH} 6$ and 8 were used. Phosphate buffer $\mathrm{pH} 6$ was prepared by mixing $13.2 \mathrm{~mL}$ of $1 \mathrm{~mol} \mathrm{~L}^{-1} \mathrm{~K}_{2} \mathrm{HPO}_{4}$ (dibasic) with $86.8 \mathrm{~mL}$ of $1 \mathrm{~mol} \mathrm{~L}^{-1} \mathrm{KH}_{2} \mathrm{PO}_{4}$ (monobasic) and the $\mathrm{pH}$ was adjusted to the exact value of $\mathrm{pH}$ 6. Also, phosphate buffer of $\mathrm{pH} 8$ was prepared by mixing $15.9 \mathrm{~mL}$ of $2 \mathrm{~mol} \mathrm{~L}^{-1} \mathrm{KH}_{2} \mathrm{PO}_{4}$ (monobasic) with $284.1 \mathrm{~mL}$ of $2 \mathrm{~mol} \mathrm{~L}^{-1} \mathrm{~K}_{2} \mathrm{HPO}_{4}$ (dibasic) and $300 \mathrm{~mL}$ distilled water then $\mathrm{pH}$ was adjusted to the exact value of $\mathrm{pH}$ 8. Urine samples were obtained from healthy volunteers and serum samples (Multi-Serum Normal, Randox Laboratories, UK) were obtained from commercial sources.

Potentiometric and $\mathrm{pH}$ measurements were carried out using HANNA instrument model-211 microprocessor $\mathrm{pH}$ meter (ROMANIA). Ag/AgCl electrode was used as an external reference electrode. AREX heating magnetic stirrer connected with a circulator thermostat was used to control the temperature of the test solutions. Type II dissolution apparatus (Erweka, Germany) was used for dissolution test. Scanning electron microscope (SEM), JEOL JSM-6060 LV-(Japan) was used for surface structure studies of carbon nanotubes sensor.

\section{Preparation of analytical solutions}

Standard drug solution: Standard pantoprazole sodium solution $0.1 \mathrm{~mol} \mathrm{~L}^{-1}$ was prepared freshly daily by dissolving $0.958 \mathrm{~g}$ in $25 \mathrm{~mL}$ distilled water. Working solutions $\left(1 \times 10^{-8}-\right.$ $1 \times 10^{-1} \mathrm{~mol} \mathrm{~L}^{-1}$ ) were prepared by appropriate dilution with distilled water.

Preparation of pantoprazole sodium tablets solution: Twenty tablets of Protonix ${ }^{\circledR} 40 \mathrm{mg} /$ tablet were carefully powdered and mixed well. Standard addition method was used for investigation of pantoprazole sodium in its tablets. An accurate amount equivalent to $100 \mathrm{mg}$ of pantoprazole sodium was dissolved in $50 \mathrm{~mL}$ distilled water, filtered in $100 \mathrm{~mL}$ measuring flask and the volume was completed to the mark using distilled water. The investigated drug was determined by recording the potential of the constructed sensors using concentration ranges of $1 \times 10^{-6}-1 \times 10^{-3}$ and $1 \times 10^{-7}-1 \times 10^{-2}$ mol L $\mathrm{L}^{-1}$ for carbon paste and chemically modified carbon nanotubes sensors, respectively.

Preparation of spiked serum and urine solutions: The proposed method was used for determination of pantoprazole sodium in human serum and urine. The human serum and urine samples were adjusted at pH 6 using phosphate buffer. For human serum, $1 \mathrm{~mL}$ of previously adjusted serum was spiked by accurately measured aliquots of pantoprazole sodium. Then the interferent species mainly protein was removed by precipitation process. $1 \mathrm{~mL}$ acetonitrile, $0.1 \mathrm{~mL}$ of $\mathrm{NaOH}(0.1 \mathrm{~mol}$ $\left.\mathrm{L}^{-1}\right)$ and $1 \mathrm{~mL}$ of $\mathrm{ZnSO}_{4} .7 \mathrm{H}_{2} \mathrm{O}(5 \% \mathrm{w} / \mathrm{v})$ were added. After centrifugation for $0.5 \mathrm{~h}$ at $3500 \mathrm{rpm}$, the clear supernatant layer was filtered through $0.5 \mu \mathrm{m}$ Milli-pore filter. For human urine, $5 \mathrm{~mL}$ of previously adjusted urine was spiked with accurate measured aliquots of pantoprazole sodium and diluted with distilled water without further treatment. Working solutions were then prepared by serial dilution to obtain pantoprazole sodium concentration ranges of $\left(1 \times 10^{-6}-1 \times 10^{-3}\right.$ and $1 \times 10^{-7}$ $\left.1 \times 10^{-2} \mathrm{~mol} \mathrm{~L}^{-1}\right)$ for carbon paste and chemically modified carbon nanotubes sensors, respectively. Pantoprazole sodium was determined using pantoprazole-phosphomolybdate fabricated sensors.

Preparation of pantoprazole-phosphomolybdate ion pair: To prepare pantoprazole-phosphomolybdate ion pair $150 \mathrm{~mL}$ of $1 \times 10^{-2} \mathrm{~mol} \mathrm{~L}^{-1}$ of pantoprazole sodium was mixed with $50 \mathrm{~mL}$ of $1 \times 10^{-2} \mathrm{~mol} \mathrm{~L}^{-1}$ of phosphomolybdic acid. The obtained precipitate was left over night and filtered using a Whatman filter paper No. 2, washed with distilled water, dried at room temperature for $24 \mathrm{~h}$ and ground to a fine powder. The composition of the ion pair $\left[\mathrm{C}_{16} \mathrm{H}_{14} \mathrm{~F}_{2} \mathrm{~N}_{3} \mathrm{NaO}_{4} \mathrm{~S}\right]_{3}\left[\mathrm{P}\left(\mathrm{Mo}_{3} \mathrm{O}_{10}\right)_{4}\right]$ which was confirmed by elemental analysis data agreed with the composition to be 3:1 (pantoprazole-phosphomolybdate). The calculated percentages of $\mathrm{C}, \mathrm{H}$ and $\mathrm{N}$ are 18.96, 1.39 and $4.15 \%$ while the found percentages were $18.90,1.36$ and $4.11 \%$, respectively.

Preparation of forced degradation products of pantoprazole sodium: Stability indicating studies were performed by inducing forced degradation of pantoprazole sodium. The preparation of forced degradation was carried out by employing various stress conditions of pantoprazole sodium. $25 \mathrm{~mL}$ of pantoprazole sodium was allowed to hydrolyze using 0.1 mol L-1 sodium hydroxide as alkaline medium, $0.05 \mathrm{~mol} \mathrm{~L}^{-1}$ hydrochloric acid as acidic medium and $0.01 \%$ hydrogen peroxide separately for $2 \mathrm{~min}$. The solution was refluxed at $80{ }^{\circ} \mathrm{C}$ for $6 \mathrm{~h}$. The solution was then cooled and neutralized then diluted with methanol. The degradation process completeness was tested on silica gel $60 \mathrm{~F}_{254}$ using ethyl acetate: methanol: glacial acetic acid $(7: 2: 1 \mathrm{v} / \mathrm{v} / \mathrm{v})$ as mobile phase. The degradation product was washed with distilled water, filtered and then dissolved in methanol. The determination of pantoprazole sodium in the presence of its forced degradation products was studied using the fabricated pantoprazole-phosphomolybdate sensors.

\section{Sensor construction}

Preparation of carbon paste sensor: The fabrication of carbon paste sensor was based on hand mixing of $60 \%$ pure graphite powder $(1-2 \mu \mathrm{m})$ with $30 \% o$-NPOE as liquid plasticizer and $10 \%$ ion pair (pantoprazole-phosphomolybdate) in an agate mortar to obtain a homogenous paste. Then the carbon paste was carefully packed in Teflon holder $(3 \mathrm{~mm}$ in diameter) in which electrical contact was made with a copper rod through the centre of the sensor holder. To produce a shiny, reproducible and smooth surface, the sensor surface was polished using a filter paper. The sensor was conditioned by dipping it in $1 \times 10^{-3} \mathrm{~mol} \mathrm{~L}^{-1}$ pantoprazole sodium solution for $12 \mathrm{~h}$. All potentiometric measurements were performed using the following cell assembly: carbon paste/test solution/Ag/ $\mathrm{AgCl}$ reference electrode.

Preparation of modified carbon nanotubes (MCNTs) carbon paste: To fabricate the modified carbon nanotubes 
sensor, the same steps as previously mentioned above preparation of carbon paste sensor was used. The modification of carbon paste was carried out using a small amount of multiwall carbon nanotubes particles and the paste was homogenously mixed. The fabricated paste was carefully packed in sensor holder and was left to dry for one day. The shiny and smooth surface was obtained by polishing the sensor surface using filter paper. The sensor was conditioned by dipping it in $1 \times 10^{-3} \mathrm{~mol} \mathrm{~L}^{-1}$ pantoprazole sodium solution for $8 \mathrm{~h}$. All potentiometric measurements were performed using the following cell assembly: Modified carbon nanotubes/test solution/ $\mathrm{Ag} / \mathrm{AgCl}$ reference electrode. The surface structure of carbon paste sensors was examined using scanning electron microscope (SEM) as shown in Fig. 2a and $2 b$.

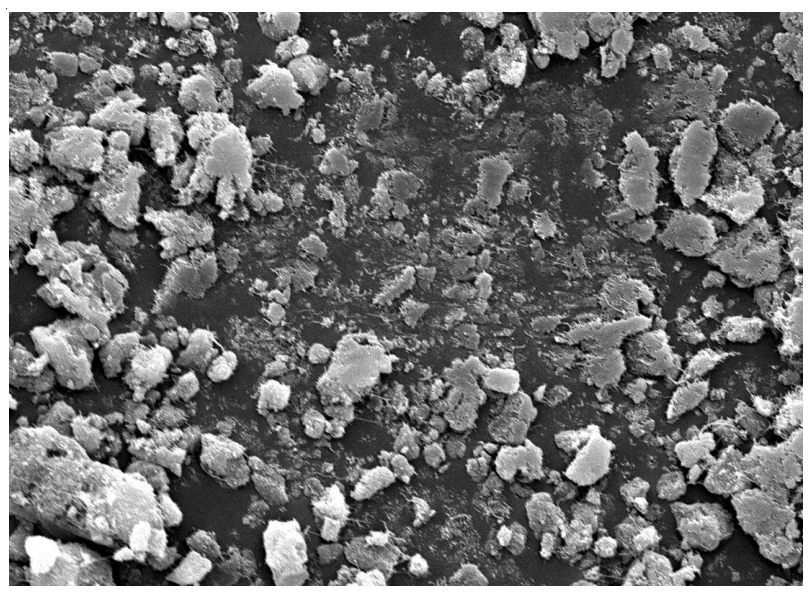

(a)

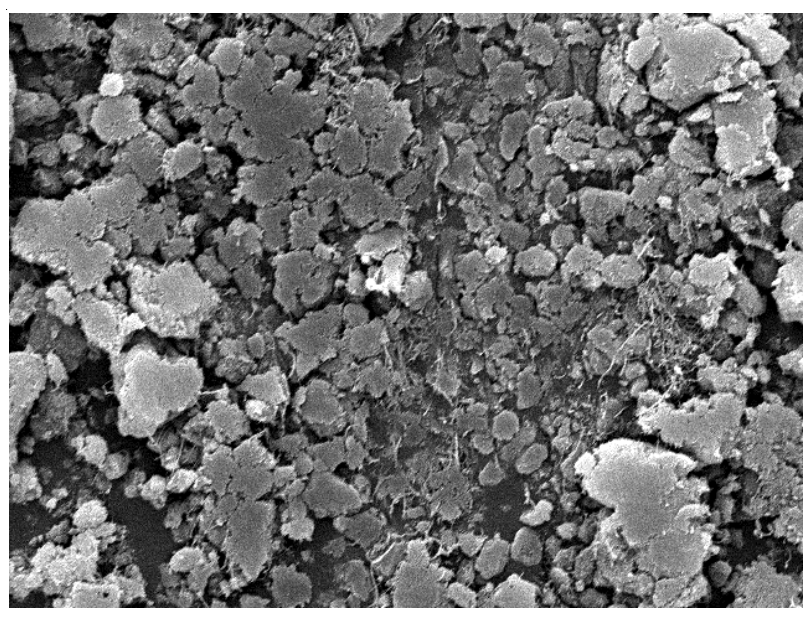

(b)

Fig. 2. Scanning electron micrographs of carbon paste sensor surface (a) carbon paste, (b) modified carbon nanotubes (MCNTs) carbon paste
Sensor calibration: Sensors calibration was carried out using the fabricated sensors in conjunction with $\mathrm{Ag} / \mathrm{AgCl}$ reference electrode. The potential of each sensor was recorded over concentration range of $1 \times 10^{-8}-1 \times 10^{-1} \mathrm{~mol} \mathrm{~L}^{-1}$. The recorded potential was plotted against the logarithm of drug concentration.

Standard addition method: Standard addition method was used for determination of pantoprazole sodium in its dosage forms. This method was based on adding small increments of the investigated drug test solution $v s$. the sensor potential. Each fabricated sensor was immersed into $50 \mathrm{~mL}$ drug test solution with unknown concentration and the equilibrium potential of $E_{1}$ was recorded. Then $0.1 \mathrm{~mL}$ of standard drug solution was added into the testing solution and the equilibrium potential $\mathrm{E}_{2}$ was recorded. The concentration of the testing sample can be obtained from the change of potential $\left(\Delta \mathrm{E}=\mathrm{E}_{2}-\mathrm{E}_{1}\right)$.

\section{RESULTS AND DISCUSSION}

\section{Optimization of sensors composition}

Composition of carbon paste sensor: The composition of carbon paste sensor was greatly affected by the main components of the sensor such as ion-pair, pure graphite powder, plasticizer and PVC matrix. The potential response of the sensor can be significantly modified by changing the relative amount of its components. So the composition of carbon paste sensor was studied using different percentage ratios 10, 18, 26 and $35 \mathrm{wt} \% o$-NPOE, 85, 75, 65 and $55 \mathrm{wt} \%$ pure graphite powder (1-2 $\mu \mathrm{m})$ and 5, 7, 9 and $10 \mathrm{wt} \%$ pantoprazole-phosphomolybdate ion pair were used. Table-1 clarified that; the best performance was achieved by using $65 \mathrm{wt} \%$ pure graphite powder $(1-2 \mu \mathrm{m})$ with $26 \mathrm{wt} \% o$-NPOE as liquid plasticizer and $9 \mathrm{wt} \%$ ion pair pantoprazole-phosphomolybdate.

Modified carbon nanotubes carbon paste sensor: The composition of modified carbon nanotubes sensor was studied by adding different wt $\%$ of carbon nanotubes. To modify carbon paste sensor 1-5 wt \% of carbon nanotubes particles was added and the performance characteristics were carefully studied. It was found that the best performance was obtained by using $26 \mathrm{wt} \% o$-NPOE, 9 wt $\%$ pantoprazole-phosphomolybdate ion pair, $60 \mathrm{wt} \%$ pure graphite powder and $5 \mathrm{wt} \%$ carbon nanotubes particles. The modification of carbon paste sensor plays an important role in the enhancement of sensor response. The improvement effect of carbon nanotubes on performance of the modified sensor can be attributed to their chemical stability and good electric conductivity properties. Also their porous surface structure and large surface area

\begin{tabular}{cccccc} 
& \multicolumn{5}{c}{ TABLE-1 } \\
& \multicolumn{5}{c}{ OPTIMIZATION OF PHOSPHOMOLYBDATE CARBON PASTE SENSOR COMPOSITION } \\
\hline \multirow{2}{*}{ No. of sensor } & \multicolumn{5}{c}{ Pantoprazole-phosphomolybdate carbon paste sensor (w/w \%) } \\
\cline { 2 - 6 } & 0 -NPOE & Graphite powder & Ion-pair & Slope & \%RSD \\
\hline 1 & 10.0 & 85.0 & 5.0 & 49.8 & 1.3 \\
2 & 18.0 & 75.0 & 7.0 & 50.0 & 0.8 \\
3 & 26.0 & 65.0 & 9.0 & 55.0 & 0.3 \\
4 & 35.0 & 55.0 & 10.0 & 53.8 & 1.1 \\
\hline \% RSD: Relative standard deviation of five determinations
\end{tabular}


facilitate a better electrolyte sensor interface that improves the wetting property with solvents.

Effect of plasticizers: The effect of plasticizers on the performance characteristics of pantoprazole-phosphomolybdate carbon paste and modified carbon nanotubes carbon paste sensors was examined using different kinds of plasticizers such as DOP with dielectric constant $(k=5.1)$, DBP $(k=6.4)$, DOS $(k=4.0)$, DBS $(k=4.5)$ and $o$-NPOE $(k=24)$. Due to their mechanical stability and permeable properties they play an important role in the enhancement of the performance characteristics of the fabricated sensors. Moreover, in case of carbon paste sensors the selection of suitable plasticizer will improve the physical properties of these sensors and promote the binding between their carbon particles.

The use of each plasticizer content ratio 50, 45, 40, 35 and 25 wt $\%$ was investigated. Table- 2 showed the effect of plasticizers on the slopes and linear concentration ranges of pantoprazole-phosphomolybdate sensors. It was cleared that the use of $o$-NPOE as plasticizer provided good performance characteristics of sensors.

Nature and response characteristics of the fabricated sensors: The nature and performance characteristics of the fabricated sensors were investigated. It was found that the pantoprazole sodium reacted with phosphomolybdic acid forming insoluble pantoprazole-phosphomolybdate ion pair. The formed ion-pair was readily soluble in organic solvent such as tetrahydrofuran (THF). Fig. 3, showed that the investigated sensors displayed Nernstain responses $(55 \pm 0.3$ and $57.3 \pm 0.8 \mathrm{mV}$ decade $\left.^{-1}\right)$ at $25^{\circ} \mathrm{C}$ over drug concentration ranges $\left(1 \times 10^{-6}-1 \times 10^{-3}\right.$ and $\left.1 \times 10^{-7}-1 \times 10^{-2} \mathrm{~mol} \mathrm{~L}^{-1}\right)$ with

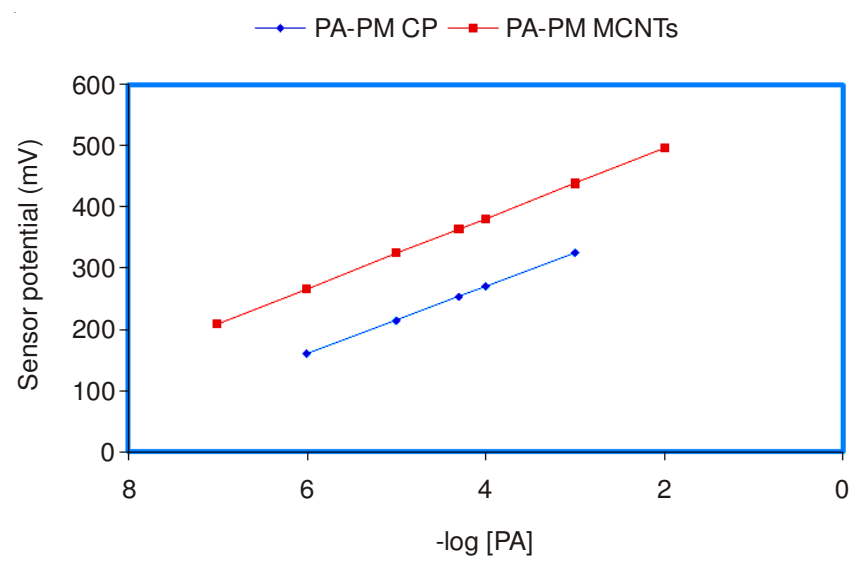

Fig. 3. Typical calibration graph of pantoprazole-phosphomolybdate carbon paste and modified carbon nanotubes sensors

lower detection limits of $\left(9.1 \times 10^{-8}\right.$ and $\left.9.8 \times 10^{-9} \mathrm{~mol} \mathrm{~L}^{-1}\right)$ for sensors I and II, respectively. Table- 3 showed that the obtained results revealed better performance characteristics for MCNTs paste sensor than carbon paste sensors. This can be attributed to the improvement effect of CNTs on the performance of the sensor due to its chemical stability and high electric conductivity properties.

Response time: The response time of sensors is the time required for the sensors to reach a stable potential reading. It was considered as one of the most important parameters which should be studied. To investigate the response time pantoprazole sodium standard solutions in the range of $1 \times 10^{-7}-1 \times 10^{-2} \mathrm{~mol}$ $\mathrm{L}^{-1}$ were used. It was found that the recorded dynamic responses for the fabricated sensors were 35 and $25 \mathrm{~s}$ for a period of 30

TABLE-2

EFFECT OF PLASTICIZERS ON THE SLOPES OF THE CALIBRATION GRAPHS OF PANTOPRAZOLE-PHOSPHOMOLYBDATE SENSORS

\begin{tabular}{|c|c|c|c|c|}
\hline \multirow{2}{*}{ Plasticizer } & \multicolumn{2}{|c|}{ Pantoprazole-phosphomolybdate carbon paste } & \multicolumn{2}{|c|}{ Pantoprazole-phosphomolybdate MCNTs } \\
\hline & Slope & Linear conc. range & Slope & Linear conc. range \\
\hline DOS & 49.6 & $1 \times 10^{-5}-1 \times 10^{-3}$ & 52.4 & $1 \times 10^{-6}-1 \times 10^{-4}$ \\
\hline DBS & 50.2 & $1 \times 10^{-5}-1 \times 10^{-3}$ & 54.2 & $1 \times 10^{-6}-1 \times 10^{-4}$ \\
\hline DOP & 53.6 & $1 \times 10^{-5}-1 \times 10^{-3}$ & 55.8 & $1 \times 10^{-6}-1 \times 10^{-3}$ \\
\hline DBP & 54.4 & $9 \times 10^{-5}-1 \times 10^{-3}$ & 56.9 & $1 \times 10^{-6}-1 \times 10^{-3}$ \\
\hline$o$-NPOE & $55.0^{*}$ & $1 \times 10^{-6}-1 \times 10^{-3}$ & $57.3^{*}$ & $1 \times 10^{-7}-1 \times 10^{-2}$ \\
\hline
\end{tabular}

TABLE-3

CRITICAL RESPONSE CHARACTERISTICS OF PANTOPRAZOLE SODIUM SENSORS

\begin{tabular}{|c|c|c|}
\hline Parameter $^{a}$ & $\begin{array}{l}\text { Pantoprazole-phosphomolybdate } \\
\text { carbon paste sensor }\end{array}$ & $\begin{array}{l}\text { Pantoprazole-phosphomolybdate modified } \\
\text { carbon nanotubes carbon paste sensor }\end{array}$ \\
\hline Slope $\left(\mathrm{mV} \mathrm{decade}{ }^{-1}\right)$ & $55.0 \pm 0.32$ & $57.3 \pm 0.84$ \\
\hline Intercept & 490.11 & 611.25 \\
\hline Regression equations & $\mathrm{E}_{\mathrm{mV}}=(55.0 \pm 0.32) \log [\mathrm{PA}]+490.11$ & $\mathrm{E}_{\mathrm{mV}}=(57.3 \pm 0.84) \log [\mathrm{PA}]+611.25$ \\
\hline Correlation coefficient (r) & 0.9997 & 0.9999 \\
\hline Linear range $\left(\mathrm{mol} \mathrm{L}^{-1}\right)$ & $1.0 \times 10^{-6}-1.0 \times 10^{-3}$ & $1.0 \times 10^{-7}-1.0 \times 10^{-2}$ \\
\hline Lower limit of detection & $9.1 \times 10^{-8}$ & $9.8 \times 10^{-9}$ \\
\hline Response time (s) & 35 & 25 \\
\hline Working $\mathrm{pH}$ range & $4-8$ & $4-8$ \\
\hline Life time (day) & 30 & 45 \\
\hline Temperature $\left({ }^{\circ} \mathrm{C}\right)$ & 25 & 25 \\
\hline Accuracy $(\%)$ & $99.6 \pm 0.73$ & $99.8 \pm 0.84$ \\
\hline Robustness $^{\mathrm{b}}$ & $99.3 \pm 0.17$ & $99.6 \pm 0.45$ \\
\hline Ruggedness $^{c}$ & $99.1 \pm 0.24$ & $99.5 \pm 0.14$ \\
\hline
\end{tabular}

${ }^{\mathrm{a}}$ Mean of six measurements ${ }^{\mathrm{b}} \mathrm{A}$ small variation in method parameters was carried out as $\mathrm{pH}$ of phosphate buffer (pH $\left.8.0 \pm 1\right)$. ${ }^{\mathrm{c}}$ Comparing the results by those obtained by different sensors assemblies using Jenway $3510 \mathrm{pH}$ meter 
and 45 days for sensors I and II, respectively without significant change in the sensor parameters.

Effect of pH: The effect of $\mathrm{pH}$ on the fabricated sensors was investigated. The test solution of $1 \times 10^{-3} \mathrm{~mol} \mathrm{~L}^{-1}$ pantoprazole sodium solution was acidified using $0.1 \mathrm{~mol} \mathrm{~L}^{-1}$ hydrochloric acid. The potential readings were recorded and then the $\mathrm{pH}$ was gradually increased using $0.1 \mathrm{~mol} \mathrm{~L}^{-1}$ sodium hydroxide. The recorded potential was plotted vs. pH. Fig. 4 showed that the fabricated pantoprazole-phosphomolybdate sensors displayed safe $\mathrm{pH}$ range at 4-8. It was noticed that below $\mathrm{pH} 4$ the potential reading was decreased due to the high acidity and the interference of $\mathrm{H}^{+}$ion. While, at higher $\mathrm{pH}$ more than 8 the sensors displayed sharp decrease in potential due to the effect of $\mathrm{OH}^{-}$on the test solution.

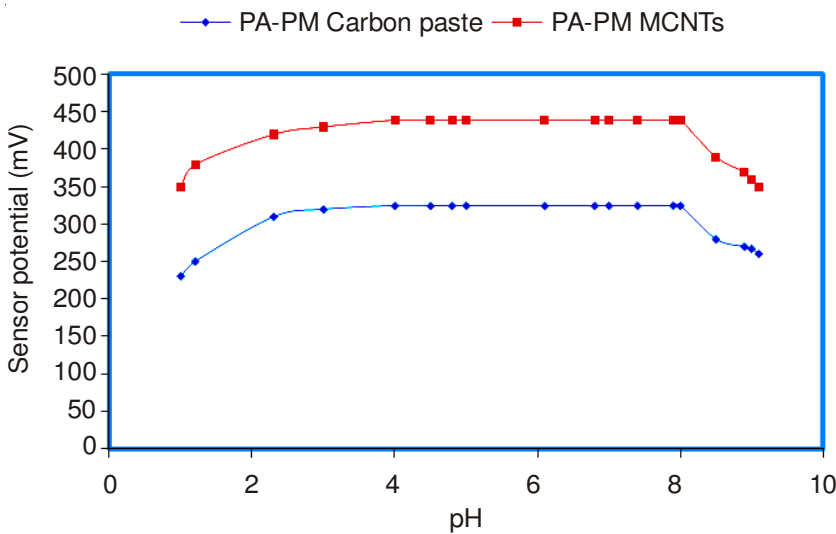

Fig. 4. Effect of $\mathrm{pH}$ on pantoprazole-phosphomolybdate sensors using 1.0 $\times 10^{-3} \mathrm{~mol} \mathrm{~L}^{-1}$ of pantoprazole sodium

Selectivity of sensors: The selectivity coefficients of the prepared sensors were investigated. The selectivity of the fabricated sensors was tested towards different common cations, sugars, amino acids and some additive substances using separate solution method ${ }^{15}$. The following equation was applied for the selectivity coefficients of the proposed sensors.

$\log \mathrm{K}^{\mathrm{pot}}{ }_{\mathrm{PA}} \cdot \mathrm{J}^{\mathrm{Z}+}=\left(\mathrm{E}_{2}-\mathrm{E}_{1}\right) / \mathrm{S}+\log [\mathrm{PA}]-\log \left[\mathrm{J}^{\mathrm{Z}+}\right]^{1 / 2}$

where, $\mathrm{E}_{1}$ is the electrode potential in $1 \times 10^{-3} \mathrm{~mol} \mathrm{~L}^{-1}$ pantoprazole sodium solution, $\mathrm{E}_{2}$ is the potential of the electrode in $1 \times 10^{-3} \mathrm{~mol} \mathrm{~L}^{-1}$ solution of the interferent ion $\mathrm{J}^{\mathrm{Zt}}$ and $\mathrm{S}$ is the slope of the calibration plot. The results reported in Table-4 clarified the high selectivity of the fabricated sensors. The main mechanism of selectivity is dependent on the matching
TABLE-4

SELECTIVITY COEFFICIENTS K ${ }^{\mathrm{Pot}}{ }_{\mathrm{PA}}^{+}{ }^{+}$FOR PA-PM SENSORS

USING $1 \times 10^{-3} \mathrm{~mol} \mathrm{~L}^{-1}$ PANTOPRAZOLE SODIUM (SEPARATE SOLUTION METHOD)

\begin{tabular}{lcc}
\hline \multirow{2}{*}{ Interferent } & \multicolumn{2}{c}{$\mathrm{K}^{\text {Pot }{ }_{\text {PA }}^{+}}$} \\
\cline { 2 - 3 } & $\begin{array}{c}\text { PA-PM Carbon Paste } \\
\text { sensor }\end{array}$ & $\begin{array}{c}\text { PA-PM -MNCTs } \\
\text { sensor }\end{array}$ \\
\hline $\mathrm{Na}^{+}$ & $4.2 \times 10^{-3}$ & $6.0 \times 10^{-3}$ \\
$\mathrm{~K}^{+}$ & $1.6 \times 10^{-3}$ & $2.1 \times 10^{-3}$ \\
$\mathrm{NH}_{4}{ }^{+}$ & $5.2 \times 10^{-3}$ & $5.3 \times 10^{-3}$ \\
$\mathrm{Ca}^{2+}$ & $1.9 \times 10^{-3}$ & $7.7 \times 10^{-3}$ \\
$\mathrm{Mg}^{2+}$ & $7.0 \times 10^{-3}$ & $8.7 \times 10^{-4}$ \\
$\mathrm{Zn}^{2+}$ & $2.6 \times 10^{-4}$ & $1.1 \times 10^{-5}$ \\
$\mathrm{Cu}^{2+}$ & $1.5 \times 10^{-4}$ & $5.8 \times 10^{-4}$ \\
$\mathrm{Fe}^{3+}$ & $1.8 \times 10^{-4}$ & $7.9 \times 10^{-4}$ \\
$\mathrm{Al}^{3+}$ & $6.9 \times 10^{-3}$ & $6.2 \times 10^{-4}$ \\
$\mathrm{Glucose}_{\text {Lactose }}$ & $9.8 \times 10^{-4}$ & $5.1 \times 10^{-4}$ \\
Sucrose & $2.3 \times 10^{-3}$ & $6.6 \times 10^{-3}$ \\
Starch & $1.1 \times 10^{-3}$ & $4.2 \times 10^{-5}$ \\
Serine & $5.6 \times 10^{-3}$ & $1.1 \times 10^{-5}$ \\
Glycine & $3.8 \times 10^{-3}$ & $8.9 \times 10^{-4}$ \\
Histadine & $2.5 \times 10^{-4}$ & $9.1 \times 10^{-4}$ \\
Thymine & $8.2 \times 10^{-4}$ & $1.2 \times 10^{-4}$ \\
Ornithine & $1.2 \times 10^{-4}$ & $1.6 \times 10^{-5}$ \\
Glutamine & $8.5 \times 10^{-4}$ & $4.5 \times 10^{-4}$ \\
\hline
\end{tabular}

between the locations of lipophilic sites in the two competing species in the bathing solution side and those present in the receptor of ion pair. The inorganic cations, sugars and some amino acids showed insignificant interferent effect during the determination of pantoprazole sodium.

Effect of temperature on the sensors performance: The effect of temperature of the test solution on sensors performance was carefully studied. This was carried out by plotting the calibration graphs (sensor potential $v s . \mathrm{p}^{\mathrm{PA}}$ ) at different test solution temperatures $\left(25,30,40,50,60\right.$ and $\left.70{ }^{\circ} \mathrm{C}\right)$ for all sensors. Table-5 summarized the slopes, usable concentration ranges and the standard sensor potential $\left(\mathrm{E}^{\circ}\right)$ at each temperature.

To determine the isothermal coefficients $\left(\mathrm{dE}^{\circ} / \mathrm{dt}\right)$ of the sensors, the standard sensor potentials $\left(\mathrm{E}^{\circ}\right)$ against normal hy drogen electrode at different temperatures were measured. This can be carried out by plotting the calibration graphs as the intercepts at $\mathrm{p}^{\mathrm{PA}}=0$ (after subtracting the values of the standard sensor potential of $\mathrm{Ag} / \mathrm{AgCl}$ electrode at these temperatures) vs. $(t-25)$ where $t$ is the temperature of test solution in ${ }^{\circ} \mathrm{C}$. The obtained straight line was according to the following equation $^{16}$ :

TABLE-5

PERFORMANCE CHARACTERISTICS OF PANTOPRAZOLE SODIUM-SENSORS AT DIFFERENT TEMPERATURES

\begin{tabular}{ccccc}
\hline Type of Sensors & Temperature ${ }^{\circ} \mathrm{C}$ & Slope $/ \mathrm{mV}$ decade ${ }^{-1}$ & Usable concentration range & $\mathrm{E}^{\circ} / \mathrm{mV}^{\mathrm{a}}$ \\
\hline & 25 & 55.0 & $1.0 \times 10^{-6}-1.0 \times 10^{-3}$ & 210 \\
PA-PM & 30 & 60.0 & $1.0 \times 10^{-6}-1.0 \times 10^{-3}$ & 215 \\
& 40 & 62.5 & $1.0 \times 10^{-6}-1.0 \times 10^{-3}$ & 226 \\
& 50 & 64.2 & $1.0 \times 10^{-6}-1.0 \times 10^{-3}$ & 241 \\
\\
60 & 65.3 & $1.0 \times 10^{-5}-1.0 \times 10^{-3}$ & 249 \\
PA-PM MCNT's & 70 & 58.0 & $1.0 \times 10^{-5}-1.0 \times 10^{-3}$ & 260 \\
& 25 & 59.3 & $1.0 \times 10^{-7}-1.0 \times 10^{-2}$ & 260 \\
& 30 & 62.1 & $5.0 \times 10^{-7}-1.0 \times 10^{-2}$ & 267 \\
& 50 & 63.7 & $5.0 \times 10^{-7}-1.0 \times 10^{-2}$ & 271 \\
\end{tabular}

${ }^{a} E^{\circ}$ : Standard sensor potential against normal hydrogen electrode (NHE) 
$\mathrm{E}^{\circ}=\mathrm{E}^{\circ}(25)+(\mathrm{dE} / \mathrm{dt})(t-25)$

The isothermal coefficients were represented from the slopes of the straight lines obtained. They were amounted to 0.00105 and $0.000421 \mathrm{~V}^{\circ} \mathrm{C}^{-1}$ for sensors I and II, respectively. These low values were revealed that the pantoprazolephosphomolybdate sensors have high thermal stability within the studied temperature range $\left(25-70{ }^{\circ} \mathrm{C}\right)$.

Effect of soaking: To study the effect of soaking time on the potential of the fabricated sensors each sensor was soaked in $1 \times 10^{-3} \mathrm{~mol} \mathrm{~L}^{-1}$ drug solution for $24 \mathrm{~h}$. The optimum soaking time was found to be 12 and $8 \mathrm{~h}$ at which the slopes of the calibration curves was $55 \pm 0.3$ and $57.3 \pm 0.8 \mathrm{mV} \mathrm{decade}^{-1}$ at $25^{\circ} \mathrm{C}$ for sensors I and II, respectively. Upon prolonged soaking the slopes were slightly decreased for different intervals 10 , $20,30,35,40$ and 45 days to be 53.9 and $55.6 \mathrm{mV} \mathrm{decade}^{-1}$ after 30 days, while continuous soaking for 45 days caused sharp decrease in sensors potential to reach $49.5 \mathrm{mV}$ decade $^{-1}$ after 35 days for pantoprazole-phosphomolybdate carbon paste sensor and $53.7 \mathrm{mV}$ decade ${ }^{-1}$ for pantoprazole-phosphomolybdate modified carbon paste sensor after 45 days.

The regeneration of pantoprazole-phosphomolybdate sensors was successfully carried out by soaking the exhausted sensor for $24 \mathrm{~h}$ in $1 \times 10^{-2} \mathrm{~mol} \mathrm{~L}^{-1}$ phosphomolybdic acid, followed by $3 \mathrm{~h}$ in $1 \times 10^{-2} \mathrm{~mol} \mathrm{~L}^{-1}$ pantoprazole sodium solution. After regeneration the fabricated pantoprazole-phosphomolybdate sensors displayed a potential response of 52.9 and 55.7 $\mathrm{mV} \mathrm{decade}{ }^{-1}$ for sensors I and II, respectively. It was found that the lifespan of the regenerated sensor is limited to 4 and $8 \mathrm{~h}$ for the previously mentioned sensors.

\section{Analytical applications}

Quantification of pantoprazole sodium: The proposed method was used directly for the determination of pantoprazole sodium in its bulk solution. The fabricated sensors were employed for recoding the mean \% recoveries. The obtained results were $99.7 \pm 0.33$ and $99.8 \pm 0.47$ for sensors I and II, respectively. Furthermore, the results obtained were encouraging, so the proposed method was applied for the determination of pantoprazole sodium in its pharmaceutical preparations; the results were $99.4 \pm 0.31$ and $99.5 \pm 0.28$ in Protonix ${ }^{\circledR}$ (40 $\mathrm{mg} /$ tablet) for the above mentioned sensors, respectively.

The fabricated sensors were successfully applied for the determination of pantoprazole sodium in biological fluids. The results obtained for determination of pantoprazole sodium in urine were $98.9 \pm 0.41$ and $99.3 \pm 0.55$ while for human serum the recorded results were $98.9 \pm 0.39$ and $99 \pm 0.59$ for sensors I and II, respectively (Table-6).

The evaluation of the proposed method was carried out by applying statistical analysis for the obtained results using student's $t$ - and $F$ - tests at $95 \%$ confidence level ${ }^{17}$. Table-7 showed that the results were in good agreement with those obtained from a reported method (a spectrophotometric method which is based on the reduction of ferric chloride by pantoprazole sodium in neutral medium and subsequent chelation of iron(II) with 1,10-phenanthroline, then the resulting red coloured chromogen is measured at $510 \mathrm{~nm})^{11}$.

Content uniformity assay of tablets: To study the content uniformity assay of pantoprazole sodium tables, ten individual tablets (Protonix ${ }^{\circledR} 40 \mathrm{mg} /$ tablet) were placed in separate 100
$\mathrm{mL}$ beakers and dissolved in $100 \mathrm{~mL}$ distilled water. Direct measurements to the investigated drug were carried out using the fabricated sensors. The mean potential was used to evaluate the content uniformity from the calibration graph. The obtained results obtained as \% recoveries and standard deviations were $99.4 \pm 0.58$ and $99.6 \pm 0.14$ for sensors I and II, respectively.

Dissolution test of tablets: The dissolution test of pantoprazole sodium (Protonix ${ }^{\circledR} 40 \mathrm{mg} /$ tablet) was carried out according to $\mathrm{USP}^{18}$ using Type II dissolution apparatus (Erweka, Germany). The dissolution medium was $1000 \mathrm{~mL}$ of $0.1 \mathrm{~mol}$ $\mathrm{L}^{-1}$ hydrochloric acid and the temperature was adjusted at 37 $\pm 0.5^{\circ} \mathrm{C}$. $75 \mathrm{rpm}$ rotation was used for $120 \mathrm{~min}$. Pantoprazolephosphomolybdate-sensor type I and II in conjunction with $\mathrm{Ag} / \mathrm{AgCl}$ reference electrode were used as detection system for recording the potential at different time intervals. After $0.5 \mathrm{~h}$, the amounts of pantoprazole sodium released were calculated from the calibration curve and represented by dissolution profile as shown in Fig. 5. The results obtained were 10 and $15 \%$. These results meet the requirements of pharmaceutical manufacturer that require not less than $10 \%$ of the drug should be dissolved within $120 \mathrm{~min}$.

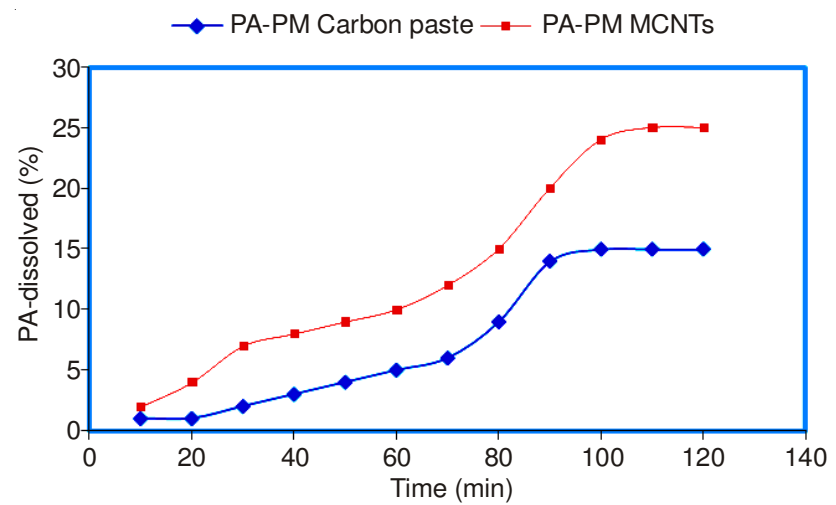

Fig. 5. Dissolution profile of Protonix ${ }^{\circledR} 40 \mathrm{mg} /$ tablet using pantoprazolephosphomolybdate sensors

Determination of pantoprazole sodium in presence of its degradation products: To determine pantoprazole sodium in the presence of its degradation products, the fabricated pantoprazole-phosphomolybdate sensors were used. The potential readings for the fabricated sensors using $1 \times 10^{-3}$ mol L ${ }^{-1}$ in the presence of $(20,40,60,80$ and $100 \%)$ of degradation products were compared with those obtained by $1 \times 10^{-3} \mathrm{~mol} \mathrm{~L}^{-1}$ pure pantoprazole sodium solution. It was found that the mean $\%$ recoveries were $99.2 \pm 0.57$ and $99.5 \pm$ 0.82 for sensors I and II, respectively indicating good selectivity and high sensitivity of the fabricated sensors for determination of pantoprazole sodium even in the presence of its degradation products.

Method validation: The proposed method was validated according to $\mathrm{ICH}^{19}$ for linearity, lower limit of detection, accuracy, precision, robustness and ruggedness.

Linearity and lower limit of detection: The fabricated pantoprazole-phosphomolybdate sensors were used to determine the method linearity. Pantoprazole sodium test solutions ranging from $1 \times 10^{-8}-1 \times 10^{-1} \mathrm{~mol} \mathrm{~L}^{-1}$ were subjected to detection systems. The linearity was determined by plotting the potentials against -log concentrations of pantoprazole sodium. 


\begin{tabular}{|c|c|c|c|c|c|c|}
\hline & ISTICAL TREATI & ENT OF DATA OB & $\begin{array}{l}\text { TABLE-6 } \\
\text { ED BY DE }\end{array}$ & IINATION OF PA & ING PA-PM SENS & \\
\hline & & PA-PM CP sensor & & & -PM MCNTs sens & \\
\hline Sample & $\begin{array}{c}\text { Taken -log conc. } \\
\left(\mathrm{mol} \mathrm{L}^{-1}\right)\end{array}$ & $\begin{array}{l}\text { Found -log conc. } \\
\left(\mathrm{mol} \mathrm{L}^{-1}\right)\end{array}$ & $\begin{array}{c}\text { Recovery } \\
(\%)\end{array}$ & $\begin{array}{l}\text { Taken -log conc. } \\
\left(\mathrm{mol} \mathrm{L}^{-1}\right)\end{array}$ & $\begin{array}{l}\text { Found -log conc. } \\
\left(\mathrm{mol} \mathrm{L}^{-1}\right)\end{array}$ & $\begin{array}{c}\text { Recovery } \\
(\%)\end{array}$ \\
\hline & 6.0 & 6.01 & 100.2 & 7.0 & 6.99 & 99.9 \\
\hline & 5.3 & 5.29 & 99.8 & 6.0 & 5.98 & 99.7 \\
\hline Pure drug & 5.0 & 4.99 & 99.8 & 5.0 & 5.01 & 100.2 \\
\hline & 4.3 & 3.28 & 99.4 & 4.0 & 3.99 & 99.8 \\
\hline & 4.0 & 3.99 & 99.8 & 3.0 & 3.01 & 100.3 \\
\hline & 3.0 & 2.98 & 99.3 & 2.0 & 1.98 & 99.0 \\
\hline$*$ Mean $\% \pm$ SD & & $99.7 \pm 0.33$ & & & $99.8 \pm 0.47$ & \\
\hline $\mathrm{n}$ & & 6 & & & 6 & \\
\hline Variance & & 0.11 & & & 0.22 & \\
\hline$\% \mathrm{SE}$ & & 0.13 & & & 0.19 & \\
\hline$\%$ RSD & & 0.33 & & & 0.47 & \\
\hline & 6.0 & 5.97 & 99.5 & 7.0 & 6.98 & 99.7 \\
\hline & 5.3 & 5.26 & 99.2 & 6.0 & 5.99 & 99.8 \\
\hline Protonix ${ }^{\circledR} 40$ & 5.0 & 4.99 & 99.8 & 5.0 & 4.98 & 99.6 \\
\hline $\mathrm{mg} / \mathrm{tablet}$ & 4.3 & 4.27 & 99.3 & 4.0 & 3.98 & 99.5 \\
\hline & 4.0 & 3.96 & 99.0 & 3.0 & 2.97 & 99.0 \\
\hline & 3.0 & 2.99 & 99.7 & 2.0 & 1.99 & 99.5 \\
\hline$*$ Mean $\% \pm$ SD & & $99.4 \pm 0.31$ & & & $99.5 \pm 0.28$ & \\
\hline & & 6 & & & 6 & \\
\hline Variance & & 0.09 & & & 0.08 & \\
\hline$\% \mathrm{SE}$ & & 0.13 & & & 0.11 & \\
\hline$\%$ RSD & & 0.31 & & & 0.28 & \\
\hline & 6.0 & 5.98 & 99.7 & 7.0 & 6.98 & 99.7 \\
\hline & 5.3 & 5.24 & 98.8 & 6.0 & 5.99 & 99.8 \\
\hline Urine sample & 5.0 & 4.95 & 99.0 & 5.0 & 4.95 & 99.0 \\
\hline & 4.3 & 4.26 & 99.0 & 4.0 & 3.97 & 99.3 \\
\hline & 4.0 & 3.94 & 98.5 & 3.0 & 2.95 & 98.3 \\
\hline & 3.0 & 2.96 & 98.7 & 2.0 & 1.99 & 99.5 \\
\hline$*$ Mean $\% \pm$ SD & & $98.9 \pm 0.41$ & & & $99.3 \pm 0.55$ & \\
\hline $\mathrm{n}$ & & 6 & & & 6 & \\
\hline Variance & & 0.17 & & & 0.30 & \\
\hline$\% \mathrm{SE}$ & & 0.17 & & & 0.22 & \\
\hline$\%$ RSD & & 0.41 & & & 0.55 & \\
\hline & 6.0 & 5.92 & 98.7 & 7.0 & 6.95 & 99.3 \\
\hline & 5.3 & 5.24 & 98.9 & 6.0 & 5.99 & 99.8 \\
\hline Serum sample & 5.0 & 4.93 & 98.6 & 5.0 & 4.95 & 99.0 \\
\hline & 4.3 & 4.26 & 99.1 & 4.0 & 3.96 & 99.0 \\
\hline & 4.0 & 3.95 & 98.8 & 3.0 & 2.94 & 98.0 \\
\hline & 3.0 & 2.96 & 98.7 & 2.0 & 1.98 & 99.0 \\
\hline$*$ Mean $\% \pm$ SD & & $98.9 \pm 0.39$ & & & $99.0 \pm 0.59$ & \\
\hline $\mathrm{n}$ & & 6 & & & 6 & \\
\hline Variance & & 0.15 & & & 0.35 & \\
\hline$\% \mathrm{SE}$ & & 0.16 & & & 0.24 & \\
\hline$\%$ RSD & & 0.39 & & & 0.59 & \\
\hline
\end{tabular}

TABLE-7

STATISTICAL TREATMENT OF DATA OBTAINED FOR THE DETERMINATION OF PA IN PROTONIX ${ }^{\circledR} 40$

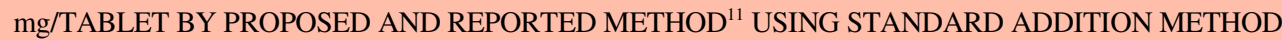

\begin{tabular}{|c|c|c|c|c|c|c|c|c|}
\hline Type of sensor & Taken $\left(\mathrm{mol} \mathrm{L}^{-1}\right)$ & Mean $\% \pm$ SD & $\mathrm{n}$ & Variance & SE & $\%$ RSD & t-test & F-test \\
\hline PA-PM carbon paste & $1.0 \times 10^{-6}-1.0 \times 10^{-2}$ & $99.4 \pm 0.31$ & 6 & 0.09 & 0.13 & 0.31 & $0.43(2.228)^{*}$ & $2.44(5.05)^{*}$ \\
\hline $\begin{array}{l}\text { PA-PM modified carbon } \\
\text { nanotubes }\end{array}$ & $1.0 \times 10^{-7}-1.0 \times 10^{-2}$ & $99.5 \pm 0.28$ & 6 & 0.08 & 0.11 & 0.28 & $0.91(2.228)^{*}$ & $2.75(5.05)^{*}$ \\
\hline Reported method [Ref. 11] & $1.0 \times 10^{-6}-1.0 \times 10^{-2}$ & $99.3 \pm 0.47$ & 6 & 0.22 & 0.19 & 0.47 & ---- & --- \\
\hline
\end{tabular}

The results obtained clarified that the constructed sensors displayed Nernstain response over linear concentration ranges of $1 \times 10^{-6}-1 \times 10^{-3}$ and $1 \times 10^{-7}-1 \times 10^{-2} \mathrm{~mol} \mathrm{~L}^{-1}$ for sensors I and II, respectively. The obtained results showed that the use of porous large surface area of modified carbon nanotubes sensor and due to its best sensor electrolyte interface, carbon nanotubes improved the performance of the sensor for the detection of small concentrations of pantoprazole sodium. 
The detection limit was calculated according to IUPAC recommendation ${ }^{20}$ which stated that the detection limit is the concentration at which the measured potential differs from that predicted by the linear regression by more than $18 \mathrm{mV}$. The detection limits were found to be about $9.1 \times 10^{-8}$ and $9.8 \times 10^{-9} \mathrm{~mol} \mathrm{~L}^{-1}$ for sensors I and II, respectively.

Robustness and ruggedness: The robustness of the proposed method was carefully studied by introducing small changes in $\mathrm{pH}$ using phosphate buffer. The $\mathrm{pH}$ of the investigated drug solutions was adjusted at $\mathrm{pH} 8 \pm 1$ and the percentage recoveries were calculated. The obtained results were $99.3 \pm 0.17$ and $99.6 \pm 0.45$ for sensors I and II, respectively. These results were closely in agreement with those obtained from standard drug solutions.

The ruggedness of the proposed method was tested using another $\mathrm{pH}$-meter (Jenway 3510). The recorded results as \% recoveries were $99.1 \pm 0.24$ and $99.5 \pm 0.14$ for the previously mentioned sensors, respectively.

Accuracy and precision: The accuracy of the proposed method was tested by determining the investigated drug in the presence of its coformulated substance magnesium stearate using standard addition method. The obtained results were calculated in terms of $\%$ recovery values. The calculated $\%$ recoveries were $99.6 \pm 0.73$ and $99.8 \pm 0.84$ for sensors I, II, respectively.

Intra-day and inter-day was used for testing the precision of the proposed method. Repeating the determination to nine replicates was performed and the calculated $\%$ RSD values were 0.56 and $0.14 \%$ for determination of pantoprazole sodium in Protonix $^{\circledR}$ (40 mg/tablet) using pantoprazole-phosphomolybdate carbon paste and modified carbon nanotubes carbon paste sensors, respectively. The above \%RSD values are less than $2 \%$ indicating good precision.

\section{Conclusion}

A new and validated potentiometric method was developed for determination of pantoprazole sodium. The developed method was based on the fabrication of carbon paste and modified carbon nanotubes sensors. The fabricated sensors were prepared using pantoprazole-phosphomolybdate. These sensors were used for determination of pantoprazole sodium in pure form, its pharmaceutical dosage forms and in biological fluids. The obtained results showed good sensitivity and high selectivity for the investigated drug. It was found that the use of modified carbon nanotubes carbon paste provided many advantages in relevant to wider concentration range, lower limit of detection and fast dynamic response. The recorded data was statistically analysed and gave excellent agreement with those obtained by other reported method.

\section{ACKNOWLEDGEMENTS}

This project was supported by King Saud University, Deanship of Scientific Research, College of Science Research Center.

\section{REFERENCES}

1. S. Budavari, The Merck Index, New Jersey, USA, edn 12, p. 1205 (1996).

2. B. Prasanna Kumar Reddy, Y. Ramanjaneya Reddy and D. Ramachandran, E.-J. Chem., 6, 489 (2009).

3. N.V.V.S.S. Raman, K.R. Reddy, A.V.S.S. Prasad and K. Ramakrishna, Chromatographia, 68, 481 (2008).

4. Z.A. El-Sherif, A.O. Mohamed, M.G. El-Bardicy and M.F. El-Tarras, Chem. Pharm. Bull. (Tokyo), 54, 814 (2006).

5. B.L. Bhaskara, U.R. Anil Kumar and K. Basavaiah, Arab. J. Chem., 4, 163 (2011).

6. N. Venugopal, A. Vijaya Bhaskar Reddy, K. Gangadhar Reddy, V. Madhavi and G. Madhavi, J. Pharm. Biomed. Anal., 70, 592 (2012).

7. M. Chen, Y. Xia, Z. Ma, L. Li, D. Zhong and X. Chen, J. Chromatogr. B Analyt. Technol. Biomed. Life Sci., 906, 85 (2012).

8. D. Bageshwar, V. Khanvilkar and V. Kadam, J. Pharm. Anal., 1, 275 (2011).

9. F. Salama, N. El-Abasawy, S.A. Abdel Razeq, M.M.F. Ismail and M.M. Fouad, J. Pharm. Biomed. Anal., 33, 411 (2003).

10. A.A. Moustafa, J. Pharm. Biomed. Anal., 22, 45 (2000).

11. Z.D. Okram and B. Kanakapura, Int. J. Chem. Tech. Res., 2, 642 (2010).

12. N. Erk, Anal. Biochem., 323, 48 (2003).

13. A. Radi, IL Farmaco, 58, 535 (2003).

14. M.S. Digge, R.S. Moon and S.G. Gsttani, Int. J. Pharm. Tech. Res., 4, 839 (2012).

15. T.S. Ma and S.S. Hassan, Organic analysis using ion selective electrodes, Vol. I and II, Academic Press, London, (1982).

16. U. Oesch, D. Ammann and W. Simon, Clin. Chem., 32, 1448 (1986).

17. J.C. Miller and J.N. Miller, Statistics for Analytical Chemistry, Ellis Horwood-Prentice Hall, Chichester, edn 3 (1993).

18. US pharmacopeia, electronic version (2013); http://www.usp.org/sites/ default/files/usp_pdf/EN/USPNF/pantoprazole Sodium Delayed Release Tablets.pdf

19. ICH Technical Requirements for Registration of Pharmaceuticals for Human Use, Complementary Guidelines on Methodology, Washington, DC, vol. 13 (1996).

20. Information Bulletin, IUPAC (1975). 